\title{
Political Islam and the United States, A Study of US Policy Towards Islamist Movements in the Middle East (cf. Arch. supra. Malika Zeghal)
}

Reading, Ithaca Press, 1999, 340 p.

\section{(2) OpenEdition}

Journals

\section{Édition électronique}

URL : http://journals.openedition.org/assr/1821

DOI : 10.4000/assr.1821

ISSN : $1777-5825$

Éditeur

Éditions de l'EHESS

\section{Édition imprimée}

Date de publication : 1 octobre 2002

ISBN : 2-222-96725-2

ISSN : 0335-5985

\section{Référence électronique}

"Political Islam and the United States, A Study of US Policy Towards Islamist Movements in the Middle East (cf. Arch. supra. Malika Zeghal) », Archives de sciences sociales des religions [En ligne], 120 | octobre - décembre 2002, document 120.52, mis en ligne le 16 novembre 2005, consulté le 30 avril 2019. URL : http://journals.openedition.org/assr/1821 ; DOI : 10.4000/assr.1821

Ce document a été généré automatiquement le 30 avril 2019

Archives de sciences sociales des religions 
Political Islam and the United States, A Study of US Policy Towards Islamist Movements in the Middle East (cf. Arch. supra. Malika Zeghal)

Reading, Ithaca Press, 1999, 340 p. 